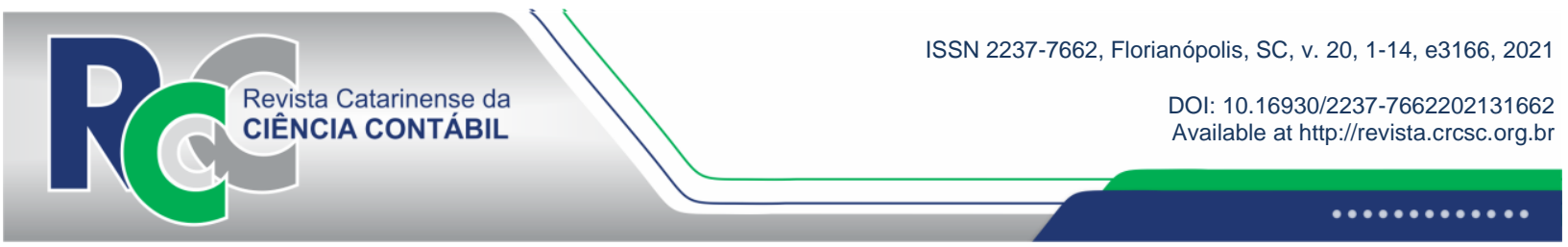

\title{
METACOGNITION, ENTREPRENEURIAL PROFILE, AND PERCEPTION OF SUCCESS
}

\author{
PEDRO MARLUS CAVALCANTE DE \\ ALBUQUERQUE ESTRELA \\ Federal University of Sergipe. Address: Rua Alcino de Oliveira \\ Neto, 45 | Luzia | 49045-800| Aracaju/SE | Brazil. \\ (1) https://orcid.org/0000-0002-3986-7467 \\ pedroestrelaufs@gmail.com
}

\author{
ADRIANO LEAL BRUNI \\ Federal University of Bahia. Address: Av. Reitor Miguel \\ Calmon, s/n | Vale do Canela | 40110-903 | Salvador/BA | \\ Brazil. \\ (D) https://orcid.org/0000-0003-0283-2778 \\ albruni@ufba.br \\ RAIMUNDO NONATO LIMA FILHO \\ University of Pernambuco. Education Authority of Vale do São \\ Francisco. Address: Cidade Universitária, s/n, Vila Eduardo | \\ 56.328-903 | Petrolina/PE | Brazil. \\ (D) https://orcid.org/0000-0003-4953-5260 \\ rnlfilho@gmail.com
}

\begin{abstract}
This study sought to identify to what extent metacognition has an effect on perceived success, mediated by the entrepreneurial profile. The sample we analyzed involved 194 alumni from Business Administration, Accounting, and Economics programs from public and private higher education institutions in the state of Sergipe. The procedures involved the use of structural equation modeling and the results indicated that goal orientation has a significant direct and indirect relationship with perceived success. Metacognitive knowledge and metacognitive experience have significant indirect relationships with perceived success, and this relationship takes place with the "self-realization" and "leader" dimensions of the entrepreneurial profile. As this study's contribution, we identified metacognitive characteristics that can be improved to enhance the perception of success, such as: frequently defining goals, understanding the relationship between tasks and goals, setting specific goals, frequently evaluating a task's progress, selecting the best option for problem solving, using assertive strategies in the past, gaining prior knowledge regarding a task, breaking problems into small parts, thinking before performing a task, using different strategies, organizing time and information, selecting important information, and using intuition to formulate strategies.
\end{abstract}

Edited in Portuguese and English. Original version in Portuguese.

Received on 03/23/2021. Revised on 05/19/2021. Accepted on 06/10/2021 by Prof. Dr. Sérgio Murilo Petri (Editor-in-Chief) and Prof. Dr. Sandro Vieira Soares (Associate Editor). Published on 7/30/2021.

Copyright () 2021 RCCC. All rights reserved. Quoting parts of articles without prior authorization is allowed, provided the source is identified. 
Keywords: Metacognition. Entrepreneurial Profile. Perception of Success. Structural Equation Modeling. Survey.

\section{INTRODUCTION}

Studies involving entrepreneurship have increased considerably in the last thirty years and gained contributions from several areas and researchers, presenting new theoretical perspectives (Ferreira, Pinto \& Miranda, 2015). Some studies have sought to understand how success occurs or why some people find it easier to detect opportunities, make decisions, and explore them.

Lima Filho and Bruni (2015) stated that at the decision making moment, there is the judgment of our own thinking, as well as the evaluation of our choices. However, according to the authors, the act of entrepreneurship also requires choices that offer the individual the possibility to evaluate the decisions. In this process, metacognitive ability arises.

Metacognition is a current and exciting topic articulated with several areas of human knowledge, such as psychology, education, sociology, mathematics, economics, accounting, and administration, among others. Metacognition can transform knowledge into professional conduct, since thinking about one's own thinking and establishing strategies expands individual potentialities toward problem solving (Lima Filho \& Bruni, 2015), which consequently can increase the perception of success. Recent studies substantiate this study's proposition by confirming a relationship between metacognition and perceived success (Earley \& Ang, 2003; Haynie, Shepherd, Mosakowski, \& Earley, 2010; Cho \& Jung, 2014). Some studies also associate the entrepreneurial profile with metacognition and perceived success (Lima Filho, 2013; Cho \& Jung, 2014).

Accordingly, this study assumes there is a significant positive relationship between metacognition and perceived success, which is mediated by the entrepreneurial profile, that is, the mediating variable modifies the relationship between the independent and dependent variables.

Based on this context, we intend to answer the following research problem: To what extent does metacognition have an effect on the perception of success, mediated by the entrepreneurial profile?

This study is justified not only for its theoretical contribution, but also for presenting empirical evidence that aids the practice of professionals, scholars, and entrepreneurs by examining the positive relationship between metacognition and perceived success. This study promotes an improvement in the learning regulatory strategy and presents the metacognitive characteristics that affect the perception of success, which can provide refinement and learning of these characteristics, and promote an improvement in the perception of success.

\section{THEORETICAL BACKGROUND}

Entrepreneurship is a broad field of study in management that has advanced in different areas of knowledge. However, the development of knowledge in this area has not occurred at the desired speed, since it encompasses numerous topics (Ferreira et al., 2015; Ferreira, Colares, Rocha \& Carvalho Junior, 2013).

One of the entrepreneurship themes is related to the continuity or discontinuity of a business and it is subject to observation. However, the concept of perceived success is less noticeable. Therefore, its observation may be more difficult, since the perception of success is tied to the individual, since psychological and subjective aspects are considered. 
Reijonen and Kompula (2007) mention that aspects such as family upbringing, social class, education, gender, and experiences can influence an individual's perception of success. In this regard, Earley and Ang (2003) argue that metacognitive awareness helps identify strategies that maximize the chances of achieving goals, i.e., metacognitive awareness can influence an individual's perception of success.

In this study, we adopted three constructs to guide the theoretical discussion and the empirical analysis: metacognition, entrepreneurial profile, and perception of success.

Metacognition is a term coined by Flavell (1979), who defined it as knowledge regarding cognitive phenomena, that is, the ability to think about one's own thinking. Rocha and Malheiro (2019) argue that metacognition is a polysemic and unseen term. Rosa, Corrêa, Passos, and Arruda (2020) say metacognition is related to the notion of thinking and thinking itself. The most common description for metacognition is the knowledge and regulation of one's own cognitive system (Lima Filho, 2013). In the same line of reasoning, Haynie and Shepherd (2009) defined metacognition as the awareness and understanding of one's own cognitive process. Gewehr, Strohschoen, and Schuck (2020) state that "metacognition is the reflection of one's own cognition, the subject's becoming aware of his or her knowledge, learning, and limitations.".

Metacognition can be understood as a set of problem-solving thinking skills, making it indispensable in dynamic and uncertain environments (Haynie et al., 2010). Ribeiro (2003, p. 110) mentions that metacognition "concerns, among other things, the knowledge of one's own knowledge, the evaluation, regulation, and organization of one's own cognitive processes". Botelho and Vargas (2021) define metacognition as a human ability related to self-knowledge and management of activities to be developed.

Metacognition can be divided into five theoretical dimensions: goal orientation, metacognitive knowledge, metacognitive experience, metacognitive choice, and metacognitive monitoring (Haynie \& Shepherd, 2009; Cho \& Jung, 2014). Segregating metacognition into dimensions enables us to know which metacognitive characteristics relate most significantly to perceived success, which can facilitate the improvement and learning of such characteristics.

Goal orientation, according to Hirst, Knippenberg, and Zhou (2009), reflect selfdevelopment beliefs and how they direct individuals to interpret and engage in their environment. It can be divided into mastery orientation, which suggests that efforts entail improved results and that skill is malleable, and performance orientation, in which skill is demonstrated by performing better than others (Jones, Davis \& Thomas, 2017).

Metacognitive knowledge concerns the conscious understanding of cognitive issues and how they relate to people, tasks, and strategies (Flavell, 1987). Both Haynie and Shepherd (2009) and Deffendi and Schelini (2016) mention that metacognitive knowledge is the extent of what people know about themselves, other people, tasks, and strategies when they are involved in a process of creating a framework of multiple decisions focused on interpreting, planning, and implementing goals in a changing environment.

Metacognitive knowledge allows one to evaluate final or intermediate results and reinforce the chosen strategy or change it, depending on the evaluations made (Ribeiro, 2003). It is stored in a mental base and it is possible to understand it, add to it, delete it, or revise it at any time (Pimentel \& Sales Júnior, 2021).

Metacognitive experiences are affective experiences in which previous situations, memories, intuitions, and emotions are employed as resources, and can make sense out of a decision context (Flavell, 1987). Haynie and Shepherd (2009) argue that past experience, emotions, and intuitions related to previous events can serve as a focused decision structure for new decisions.

Deffendi and Schelini (2016) further point out that the metacognitive experience aims to inform the individual about his or her progress in a particular task or activity, as well as 
difficulties and the evolution obtained in the process, in addition to showing what is possible to accomplish.

Metacognitive choice or strategy takes place when the individual engages in a process of selecting multiple decisions, seeking the best way to interpret, plan, and implement a response to manage a change of environment (Haynie \& Shepherd, 2009). Haynie et al. (2010) state that this dimension refers to the structure formulated by the entrepreneur and serves to evaluate multiple responses and alternatives to processing the entrepreneurial task.

Metacognitive monitoring, on the other hand, allows the individual to process, observe, reflect on, and experiment with his or her own cognitive processes (Flavell, 1979). Monitoring is the pursuit of feedback to reassess the other metacognitive dimensions aimed at managing a change of environment (Flavell, 1979; Haynie \& Shepherd, 2009). Monitoring is an evaluation of the decisions made, aiming to improve the outcome (Star, 2020).

Another crucial construct in this study is the entrepreneurial profile. Lima Filho and Bruni (2015) point out that entrepreneurship education can be understood as a path that stimulates the entrepreneurial spirit and behavior of people Moreira, Alves, Andreassi, \& Braga, (2020). Ferreira et al. (2015) argue that research on this topic has grown over the last thirty years and has attracted more attention over time.

Oosterbeek, Praag, and Ijsselstein (2010) mention that an individual with a higher level of concentration of entrepreneurial characteristics and competencies has been used to compare groups of individuals with a higher entrepreneurial profile with other surveyed groups.

Schmidt and Bohnenberger (2009) created a framework with the entrepreneur profile's characteristics: a) self-efficacious, b) risk-taker, c) planner, d) detects opportunities, e) persistent, f) sociable, g) innovative, and h) leadership. This study treats the entrepreneurial profile as a mediator in the relationship between metacognition and perceived success. To justify this role, Lima Filho and Bruni (2015) point out that the entrepreneur can use any strategy and that metacognitive awareness identifies metacognitive strategies that maximize the probability of achieving a goal.

The other key construct in this study is perceived success. There is a disparity of definitions about success because of its numerous ways of measurement, but while some researchers attempt to study the conditions for achieving success, they do not offer unanimous conclusions, making the determinant of success remain an intriguing and unexplored area (Staniewsky \& Awruk, 2017).

There are two ways to evaluate success: one focused on the entrepreneur's personal side and the other on the enterprise's economic and financial indicators. In this study, we have used indicators dealing with personality and an individual's specific skills, behavioral patterns, and attitudes. This is justified because the metacognition dimensions raise questions of a personal nature.

Understanding the concept of success requires a subjective perception, considering factors such as satisfaction, autonomy, and work-family balance (Reijonen \& Komppula, 2007). This means that success can be understood as the set of professional and personal achievements.

Costa (2013) adds the personal side of success. He argues that success is related to financial results, promotions, adaptability, work identity, visibility, life-work balance, personal fulfillment, sense of pride, and recognition.

Dries, Pepermans, and Carlier (2008) proposed a multidimensional model on career, divided into four quadrants. Costa and Dutra (2011) explain that quadrant I corresponds to interpersonal achievements, such as performance, promotion, and real contribution. Quadrant II refers to intrapersonal achievements and contains two regions: development and creativity. Quadrant III refers to intrapersonal feelings, related to oneself, and contains two regions of meaning: security and satisfaction. Quadrant IV relates to interpersonal feelings, linked to the 
relationship with others: recognition, which refers to the feeling of reward for one's efforts, cooperation, and perceived contribution.

\section{METHODOLOGICAL PROCEDURES}

This study is confirmatory and, according to Long (1983), starting from the premise that a theory exists about the measurement of variables regarding factors, it seeks confirmation of a hypothesized theory. It fits the hypothetical-deductive method, with a quantitative character.

The data collection strategy we used was a survey, of the explanatory type, i.e., giving guarantee of anonymity to the sample, since this method ensures confidentiality and privacy to the participants, encouraging them to provide more reliable information.

To test the relationships of the variables, as well as to test the chosen model, this study uses the structural equation model estimated by partial least squares (MEE-PLS). We used R Core Team 2019 software - matrixpls package for data analysis.

Aiming to answer the research problem, we proposed six hypotheses. The first five seek to relate the dimensions of metacognition to perceived success. The sixth hypothesis aims to measure the mediating effect of the entrepreneurial profile on the relationship between metacognition and perceived success. The six hypotheses are:

$\mathrm{H}_{1}$ - Goal orientation positively influences perceived success;

$\mathrm{H}_{2}$ - Metacognitive knowledge positively influences perceived success;

$\mathrm{H}_{3}$ - Metacognitive experience positively influences perceived success;

$\mathrm{H}_{4}$ - Metacognitive choice positively influences perceived success;

$\mathrm{H}_{5}$ - Metacognitive monitoring positively influences perceived success;

$\mathrm{H}_{6}$ - Entrepreneurial profile mediates the relationship between metacognition and perceived success.

The first hypothesis is grounded in the studies of Cho and Jung (2014) and Haynie and Shepherd (2009). The second is linked to the studies of Haynie and Shepherd (2009), Earley and Ang (2003), and Urban (2012). The third (H3) is connected to the studies of Haynie et al. (2010) and Flavell (1987). The fourth (H4) is supported by the studies of Urban (2012) and Haynie and Shepherd (2009). The fifth hypothesis (H5) is anchored in the study of Haynie et al. (2010). Finally, regarding the sixth hypothesis (H6), we found no studies proving the mediating effect of the entrepreneurial profile on the relationship between metacognition and perceived success, so this is a theoretical-empirical contribution that this study seeks to promote.

The data collection instruments were composed of closed questions, based on five-point Likert-type scales. The participants were only allowed to answer one single alternative per question in the entire questionnaire, with the exception of the socioeconomic block.

For the items related to metacognition, we used the study by Haynie and Shepherd (2009). We divided the questionnaire into five metacognitive dimensions.

For the questions referring to the entrepreneurial profile, we adopted the questionnaire developed by Schimidt and Bohnenberger (2009), which divides the instrument into six blocks: a) self-realization, b) leader, c) planner, d) innovator, e) risk-taker, and f) sociable.

Regarding the measurement of perceived success, we used a scale developed by Costa (2013), who used the multidimensional model of Dries et al. (2008).

We collected data by applying an electronic questionnaire via Survey Monkey, made available by e-mail or via a messaging application.

The survey respondents are alumni from Business Administration, Accounting, and Economics programs from public and private institutions in the state of Sergipe, according to accessibility criteria. We selected these programs because they may present different 
entrepreneurial profiles - formal, non-formal or non-entrepreneurial -, besides being management-oriented programs. (2016):

Regarding sample size, we used the inverse square root model of Kock and Hadaya

$$
\widehat{N}>\left(\frac{Z_{0.95}+z_{0.80}}{|\beta|_{\min }}\right)^{2}
$$

Where $\mathrm{N}$ is the minimum sample size, $\mathrm{Z}_{0.95}$ is the standard normal distribution score associated with the adopted confidence level $(95 \%), \mathrm{Z}_{0.80}$ is the standard normal distribution score associated with the adopted test power $(80 \%)$, and $\beta_{\min }$ is the smallest observed path coefficient (0.18), i.e., it represents the absolute value of the statistically significant path coefficient with the minimum magnitude in the model.

Thus, we set the minimum sample size at 191 participants. However, we obtained 225 responses, and after excluding responses from invalidated questionnaires, a total of 194 responses remained.

The measurement model in this study is reflective because, according to Hair, Hult, Ringle, Sarstedt, and Thiele (2017), the items in each construct are assumed to be manifestations of the adjacent construct. Therefore, the measurement model evaluation comprises three assumptions used in reflective models: internal consistency, convergent validity, and discriminant validity (Hair et al., 2017).

The most common measure used for internal consistency is Cronbach's Alpha, but it is sensitive to the number of items in the scale (Dijkstra \& Henseler, 2015; Lima Filho \& Nova, 2020). Then, we adopted composite reliability (CR), which ranges from 0 to 1 , where high values indicate greater internal consistency.

In the convergent validity - which, according to Cheah, Sarstedt, Ringle, Ramayah, and Ting (2018), comprises the intensity with which a measure is positively related to the construct's alternative measures - we used the average variance extracted (AVE) and the items' factor loadings. AVE values greater than $50 \%$ indicate that the construct is unidimensional and has convergent validity. Nevertheless, the square root of the factor loading of an item indicates how much of its variance is explained by the construct and needs to be greater than 0.5 , indicating that factor loadings should be greater than $0.708(\sqrt{0.5})$.

However, if you find factor loadings between 0.4 and 0.7 , you should remove items with caution. You should only exclude the item in this range if its removal amplifies to favorable CR and AVE levels. Otherwise, you retain the item (Cheah et al., 2018).

Discriminant validity is how unique each dimension is, i.e., different from the other dimensions (Hair et al., 2017). To assess discriminant validity, we used the heterotrait-monotrait ratio (HTMT) criterion. Henseler, Ringle, and Sarstedt (2015) suggest two cut-off points for HTMT: 0.85, when the theory is well established and 0.90, when it is a developing theory.

After validating the constructs' consistency, we proceeded to analyze the structural model, that is, to evaluate the predictive capabilities and the relationships among the constructs. The main criteria we used were the significance of the path coefficients between the constructs $\left(\mathrm{R}^{2}\right)$, effect size $\left(\mathrm{f}^{2}\right)$, predictive relevance $\left(\mathrm{Q}^{2}\right)$, and effect size $\left(\mathrm{q}^{2}\right)$ (Hair et al., 2017). The coefficients are standardized within the range -1 to 1 , where values close to $|1|$ indicate strong relationships and values close to 0 indicate weak relationships. Positive values indicate direct relationship and negative values indicate indirect relationship (Hair et al., 2017).

Processing of the research model involving the relationships between the constructs and their dimensions by means of the MEE-PLS technique resulted in the research model presented in Figure 1. 


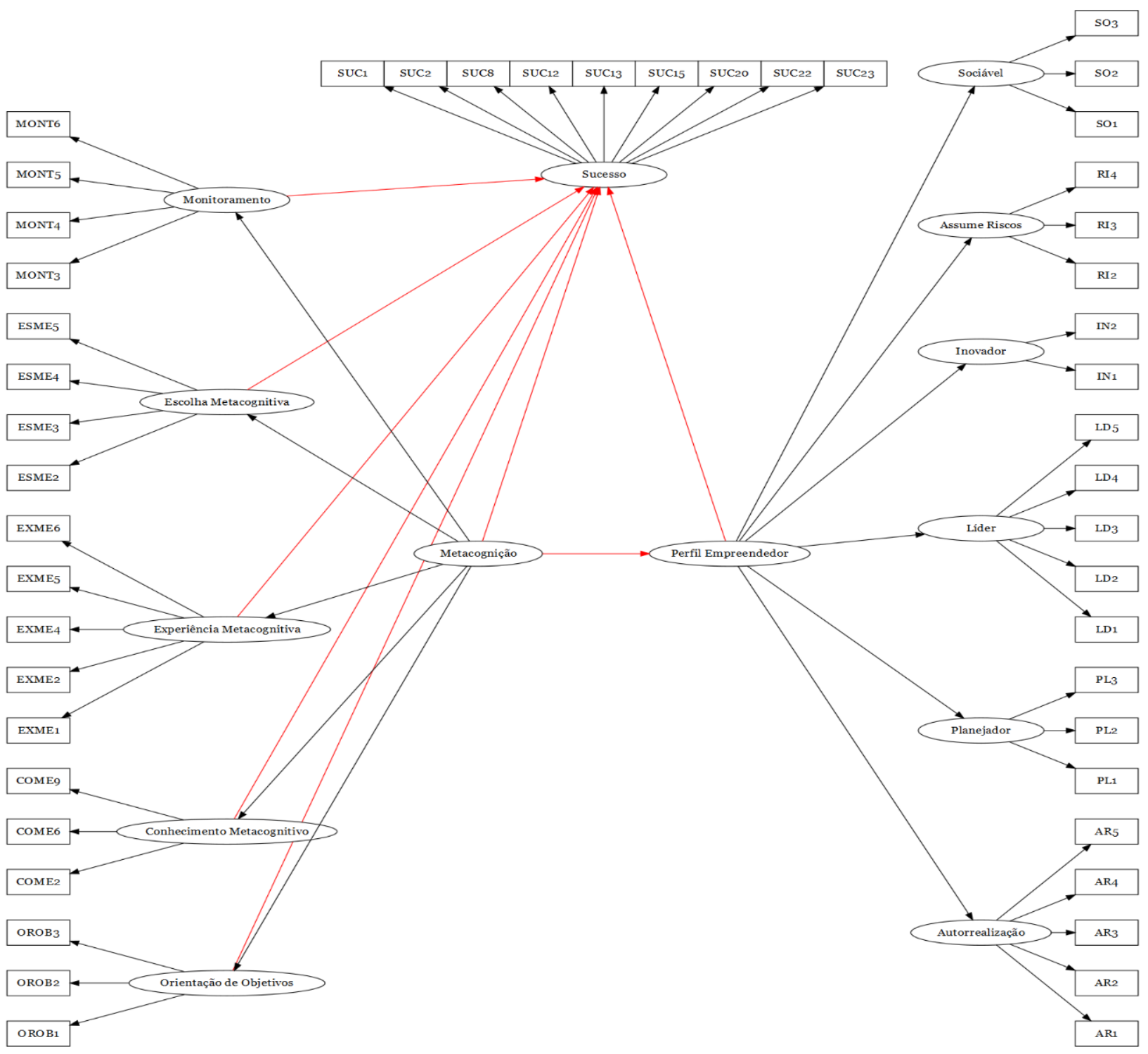

Figure 1. Final Measurement Model

Source: Prepared by the author (2021).

The model presented HTMT values lower than 0.9, indicating discriminant validity.

Table 1 presents the values for the assumptions of the measurement model. In the selfrealization, innovative, leader, planner, and sociable dimensions, we did not exclude any items and the measurement model assumptions were met. The dimensions metacognitive knowledge, metacognitive choice, metacognitive experience, monitoring, goal orientation, risk taking, and success, due to violations in the convergent validity assumption (AVE $<0.5$ and factor loading lower than 0.4 or 0.7 ), the exclusion of some items was necessary. The internal consistency assumption $(0.6<\mathrm{CR}<0.9)$ was not violated. 
Table 1

Evaluation of the Measurement Model Assumptions

\begin{tabular}{|c|c|c|c|c|c|c|c|c|}
\hline & \multicolumn{4}{|c|}{ Initial Model } & \multicolumn{4}{|c|}{ Final Model } \\
\hline & $\lambda$ & $\alpha$ & $\mathbf{C R}$ & AVE & $\lambda$ & $\alpha$ & $\mathbf{C R}$ & AVE \\
\hline Self-realization & & 0.7623 & 0.8381 & 0.5091 & & 0.7623 & 0.8386 & 0.5100 \\
\hline AR01 & 0.6691 & & & & 0.6785 & & & \\
\hline AR02 & 0.7376 & & & & 0.7447 & & & \\
\hline AR03 & 0.7062 & & & & 0.6984 & & & \\
\hline AR04 & 0.7060 & & & & 0.6968 & & & \\
\hline AR05 & 0.7459 & & & & 0.7493 & & & \\
\hline Metacognitive Knowledge & & 0.6457 & 0.7286 & 0.2326 & & 0.5151 & 0.7513 & 0.5044 \\
\hline COME02 & 0.6075 & & & & 0.6522 & & & \\
\hline COME06 & 0.6741 & & & & 0.8084 & & & \\
\hline COME09 & 0.6245 & & & & 0.6590 & & & \\
\hline Metacognitive Choice & & 0.7521 & 0.8267 & 0.4909 & & 0.7086 & 0.8201 & 0.5331 \\
\hline ESME01 & 0.7609 & & & & 0.7610 & & & \\
\hline ESME03 & 0.7659 & & & & 0.7393 & & & \\
\hline ESME04 & 0.6730 & & & & 0.6725 & & & \\
\hline ESME05 & 0.7140 & & & & 0.7447 & & & \\
\hline Metacognitive Experience & & 0.7562 & 0.8227 & 0.3763 & & 0.7637 & 0.8405 & 0.5133 \\
\hline EXME01 & 0.6970 & & & & 0.7324 & & & \\
\hline EXME02 & 0.6611 & & & & 0.6907 & & & \\
\hline EXME04 & 0.6868 & & & & 0.7144 & & & \\
\hline EXME05 & 0.7317 & & & & 0.7468 & & & \\
\hline EXME06 & 0.6813 & & & & 0.6964 & & & \\
\hline Innovative & & 0.7161 & 0.8755 & 0.7785 & & 0.7161 & 0.8757 & 0.7788 \\
\hline IN01 & 0.8703 & & & & 0.8773 & & & \\
\hline IN02 & 0.8942 & & & & 0.8877 & & & \\
\hline Leader & & 0.7888 & 0.8567 & 0.5490 & & 0.7888 & 0.8563 & 0.5488 \\
\hline LD01 & 0.6846 & & & & 0.6852 & & & \\
\hline LD02 & 0.7765 & & & & 0.7865 & & & \\
\hline LD03 & 0.8598 & & & & 0.8672 & & & \\
\hline LD04 & 0.7781 & & & & 0.7709 & & & \\
\hline LD05 & 0.5734 & & & & 0.5564 & & & \\
\hline Monitoring & & 0.7185 & 0.8046 & 0.3744 & & 0.6859 & 0.8069 & 0.5115 \\
\hline MONT03 & 0.7004 & & & & 0.7704 & & & \\
\hline MONT04 & 0.6126 & & & & 0.7204 & & & \\
\hline MONT05 & 0.6301 & & & & 0.6734 & & & \\
\hline MONT06 & 0.6369 & & & & 0.6929 & & & \\
\hline Goal Orientation & & 0.7002 & 0.8004 & 0.4467 & & 0.6225 & 0.7974 & 0.5687 \\
\hline OROB01 & 0.7036 & & & & 0.8100 & & & \\
\hline OROB02 & 0.7089 & & & & 0.7633 & & & \\
\hline OROB03 & 0.6937 & & & & 0.6837 & & & \\
\hline Planner & & 0.7858 & 0.8749 & 0.7003 & & 0.7858 & 0.8749 & 0.7004 \\
\hline PL01 & 0.8104 & & & & 0.8023 & & & \\
\hline PL02 & 0.7991 & & & & 0.8030 & & & \\
\hline PL03 & 0.8976 & & & & 0.9016 & & & \\
\hline Risk-taker & & 0.5439 & 0.7257 & 0.4235 & & 0.6523 & 0.7868 & 0.5549 \\
\hline RI02 & 0.6753 & & & & 0.6648 & & & \\
\hline RI03 & 0.8476 & & & & 0.8585 & & & \\
\hline RI04 & 0.6621 & & & & 0.6970 & & & \\
\hline Sociable & & 0.7096 & 0.8338 & 0.6264 & & 0.7096 & 0.8351 & 0.6283 \\
\hline SO01 & 0.7281 & & & & 0.7444 & & & \\
\hline SO02 & 0.8188 & & & & 0.8153 & & & \\
\hline SO03 & 0.8239 & & & & 0.8162 & & & \\
\hline Success & & 0.9440 & 0.9483 & 0.3096 & & 0.8754 & 0.9003 & 0.5013 \\
\hline SUC01 & 0.6735 & & & & 0.6697 & & & \\
\hline SUC02 & 0.6682 & & & & 0.6822 & & & \\
\hline SUC08 & 0.6628 & & & & 0.6818 & & & \\
\hline SUC12 & 0.6531 & & & & 0.7515 & & & \\
\hline SUC13 & 0.6355 & & & & 0.7127 & & & \\
\hline SUC15 & 0.6653 & & & & 0.7094 & & & \\
\hline SUC20 & 0.6896 & & & & 0.7212 & & & \\
\hline SUC22 & 0.6059 & & & & 0.7001 & & & \\
\hline
\end{tabular}

Caption: $\lambda$ - factor loading. $\alpha$ - Cronbach's Alpha. CR - Composite Reliability. AVE - Average Variance Extracted.

Source: Prepared by the author (2021).

Furthermore, since metacognition and entrepreneurial profile are not directly measured dimensions, we propose the use of second-order dimensions, the level at which dimensions 
generate dimensions. This study estimated the reflexive-reflexive type model using the two-stage method (Sarstedt \& Cheah, 2019). The entire proposed procedure described above for validating the consistency of the second-order constructs should be repeated.

Regarding discriminant validity, the second-order model presented HTMT values lower than 0.9 , indicating existence of discriminant validity.

Table 2 presents the values obtained for the measurement model assumptions. In the metacognition and entrepreneurial profile dimensions, there were no violations in the convergent validity assumption (AVE<0.5 and factor loadings lower than 0.4 or 0.7 ). The internal consistency assumption $(0.6<\mathrm{CR}<0.9)$ was also not violated.

Table 2

\section{Evaluation of Second Order Measurement Model Assumptions}

\begin{tabular}{lcccc} 
& $\boldsymbol{\lambda}$ & CR & AVE & $\boldsymbol{\alpha}$ \\
\hline Metacognition & & 0.844 & 0.523 & 0.770 \\
Goal Orientation & 0.660 & & & \\
Metacognitive Knowledge & 0.735 & & & \\
Metacognitive Experience & 0.829 & & & \\
Metacognitive Choice & 0.598 & & & \\
Monitoring & 0.772 & & & \\
Entrepreneurial Profile. & & 0.855 & 0.503 & 0.795 \\
Self-realization & 0.835 & & & \\
Planner & 0.711 & & & \\
Leader & 0.869 & & & \\
Innovative & 0.551 & & & \\
Risk-taker & 0.665 & & & \\
Sociable & 0.559 & & & \\
\hline
\end{tabular}

Caption: $\lambda$ : factor loading; $\alpha$ : Cronbach's Alpha; CR: Composite Reliability; AVE: Average Variance Extracted. Source: Prepared by the author (2021).

\section{RESULTS}

This study followed the steps proposed by Hair, Gabriel, and Patel (2014) aiming to determine the direct and indirect effects. The first step, according to Table 3, was to verify the direct effect between the independent variable and the dependent one, without the inclusion of the mediator variable.

The constructs goal orientation, metacognitive knowledge, metacognitive experience, and monitoring present a significant direct relationship with perceived success with $\mathrm{f}^{2}$ (effect size) between 0.021 and 0.101 , supporting the relationship.

Therefore, of the first five hypotheses, four have been confirmed. Only H4 was not confirmed. Thus, the confirmations of hypotheses H1, H2, H3, and H5 corroborated the studies of Pajares, Britner, and Valiante (2000), Haynie and Shepherd (2009), Cho and Jung (2014), and Jones, Davis, and Thomas (2017). Hence, improvement and learning in the dimensions goal orientation, metacognitive knowledge, metacognitive experience, and monitoring have a positive effect on perceived success.

On the goal orientation dimension, there was an effect that was considered small (Cohen, 1988). The direct effect presented an effect size $\left(\mathrm{f}^{2}\right)$ of 0.082 and a significance level (p-value) lower than 0.001 . Therefore, goal orientation has a significant direct relationship with perceived success.

Regarding the metacognitive knowledge dimension, a significant direct effect with perceived success was also demonstrated. This relationship had $\mathrm{f}^{2} 0.101$, considered small, and a 
significance level lower than 0.001. Thus, metacognitive knowledge has a significant direct relationship with perceived success.

As far as metacognitive experience is concerned, there is a direct significant effect in its relationship with perceived success. This relationship presented an effect size of 0.085 and a significance level lower than 0.001 , supporting hypothesis H3. Hence, the metacognitive experience has a significant direct relationship with the perception of success. However, the effect size is considered small (Cohen, 1988).

Metacognitive monitoring also presented significant direct effect with perceived success. In this relationship, the effect size was 0.021 and the significance level was 0.009 , supporting hypothesis H5. Although the effect is considered small, there is a significant direct relationship between metacognitive monitoring and perceived success.

Metacognitive choice presented no significant direct effect with the dependent variable. The effect size was 0.005 and the p-value was 0.152. In this case, there was no support for hypothesis $\mathrm{H} 4$.

Table 3

Direct Effect Between Metacognitive Dimensions and Perception of Success

\begin{tabular}{lcccccc}
\hline \multicolumn{1}{c}{ Independent } & Dependent & $\mathbf{B}$ & $\mathbf{f}^{2}$ & $\mathbf{T}$ & p-value & Support \\
\hline Goal Orientation & & 0.232 & 0.082 & 3.391 & $<0.001$ & Yes \\
Metacognitive Knowledge & & 0.268 & 0.101 & 3.701 & $<0.001$ & Yes \\
Metacognitive Experience & Success & 0.273 & 0.085 & 3.611 & $<0.001$ & Yes \\
Metacognitive Choice & & 0.061 & 0.005 & 0.973 & 0.152 & No \\
Monitoring & & 0.131 & 0.021 & 2.115 & 0.009 & Yes \\
\hline
\end{tabular}

Source: Prepared by the author (2021).

The second step was to evaluate the effect of the mediating variable (entrepreneurial profile) on the relationship between metacognition and perceived success. Aiming to evaluate hypothesis 6 , according to Table 4 , we performed the verification of the direct, indirect, and total effect between metacognition and perception of success mediated by entrepreneurial profile.

Table 4

\begin{tabular}{lcccccc}
\multicolumn{6}{l}{ Second Order Structural Model $~$} & Direct Relationship \\
\hline Effect & $\mathbf{B}$ & $\mathbf{f}^{\mathbf{2}}$ & $\mathbf{T}$ & $\mathbf{p}$-value & IC95\% & Support \\
\hline Total & 0.705 & 0.676 & 19.409 & $<\mathbf{0 . 0 0 0 1}$ & $0.638 ; 0.780$ & Yes \\
Direct & 0.304 & 0.162 & 5.194 & $\mathbf{0 . 0 0 0 1}$ & $0.184 ; 0.410$ & Yes \\
Indirect & 0.402 & 0.514 & 8.690 & $\mathbf{< 0 . 0 0 0 1}$ & $0.324 ; 0.509$ & Yes \\
\hline
\end{tabular}

Source: Prepared by the author (2021).

We can state metacognition directly influences the perception of success and this relationship is partly mediated by the entrepreneurial profile. Regarding the direct relationship, metacognition presented an effect size of 0.162, considered medium, and a significance level lower than 0.001. By inserting the mediating variable entrepreneurial profile, the effect size was considered large (0.514) and the significance level lower than 0.001, supporting hypothesis H6. Therefore, metacognition presents a significant direct relationship with perceived success, and, inserting the mediating variable entrepreneurial profile, there is a significant indirect relationship between metacognition and perceived success. 


\section{FINAL CONSIDERATIONS}

This study aimed to identify whether metacognition has a significant relationship with perceived success and whether the entrepreneurial profile plays a mediating role in this relationship. We applied the MEE-PLS for model validation and hypothesis testing.

We applied psychometric instruments to measure three constructs: a) metacognition, b) entrepreneurial profile, and c) perception of success. We evaluated the assumptions of internal consistency and convergent and discriminant validity, arriving at a final model. After the exclusions of the non-relevant items, questions from all sub-items of each instrument remained, which consequently kept all categories in the model.

This study results show that goal orientation, metacognitive knowledge, metacognitive experience, and metacognitive monitoring present significant direct relationship with perceived success, confirming $\mathrm{H} 1, \mathrm{H} 2, \mathrm{H} 3$, and $\mathrm{H} 5$. The results also evidenced that metacognitive choice has no significant direct relationship with perceived success, i.e., H4 was not confirmed.

Using the second-order model, this study found that metacognition has a significant direct relationship with perceived success and the effect size is considered medium (Cohen, 1988). By inserting the mediating variable, the relationship between metacognition and perceived success presented effect size considered large, supporting hypothesis H6.

This study advances this line of research by presenting new empirical evidence that there is indeed a relationship between metacognition and perceived success. It also contributes by highlighting the metacognitive characteristics that should be worked on to improve the perception of success. Regarding goal orientation, characteristics such as frequently defining goals, understanding the relationship between tasks and goals, setting specific goals, and frequently evaluating the progress of a task should be improved. As far as metacognitive knowledge is concerned, one should encourage the learning and improvement of characteristics such as selecting the best option for problem solving, using assertive strategies in the past, gaining prior knowledge of a task, as well as breaking down problems into small parts. On the metacognitive experience, one should learn and refine characteristics such as thinking before performing a task, using different strategies, organizing time and information, selecting important information, and using intuition to formulate strategies. As for monitoring, one should try to improve features such as reassessing information, being aware of strategies to be used, analyzing the usefulness of strategies, checking the understanding of the problem, and evaluating the success of a new task.

This study can still contribute to future studies as an instrument of scientific investigation related to metacognition, from a conceptual model, as well as related to the entrepreneurial profile and the perception of success, besides being a new possibility to examine metacognition.

This study presents theoretical and practical contributions. The theoretical contributions are in offering a current theoretical reference about a line of research that is still scarce in the national context. As for practical contributions, this study offers empirical findings that may help administrators, accountants, economists, professors, higher education institutions, and professionals understand metacognition and its impact on perceived success.

\section{REFERENCES}

Botelho, P., \& Vargas, D. S. (2021). Inferências e atividades de leitura: cognição e metacognição em sala de aula. Cad. Est. Ling., 63, 1-14.

Cheah, Jun-Hwa, Sarstedt, M., Ringle, C. M., Ramayah, T., \& Ting, H. (2018). Convergent validity assessment of formatively measured constructs in PLS-SEM: On using single-item 
versus multi-item measures in redundancy analyses. International Journal of Contemporary Hospitality Management, 30(11), 3192-3210.

Cho, Y. S., \& Jung, J. Y. (2014). The relationship between metacognition, entrepreneurial orientation, and firm performance: an empirical investigation. Academy of Entrepreneurship Journal, 20(2), 71-84.

Cohen, J. (1988). Statistical Power Analysis for the Behavioral Sciences (2a.ed.). Hillsdale, NJ: Lawrence Erlbaum Associates.

Costa, L. V., \& Dutra, J. (2011). Avaliação da carreira no mundo contemporâneo: proposta de um modelo de três dimensões. Recape - Revista de Carreiras e Pessoas, 1(01), 1-22.

Costa, L. V. (2013). Construção e Validação de uma Escala de Percepção de Sucesso na Carreira. Revista RECAPE, 3(1).

Deffendi, L. T., \& Schelini, P. W. (2016). O monitoramento metacognitivo em tarefas que envolvem a criatividade verbal. Psicologia: Teoria e Pesquisa, 32(3),1-8.

Dijkstra, T. K., \& Henseler, J. (2015). Consistent partial least squares path modeling. MIS quarterly, 39(2).

Dries, N., Pepermans, R., \& Carlier, O. (2008). Career success: Constructing a multidimensional model. Journal of Vocational Behavior, 73(2), 254-267.

Earley, P. C. \& Ang, S. (2003). Cultura intelligence: individuals interections across cultures. Stanford, Califórnia: Stanford Business Books.

Estrela, P. M. C. de A. (2020). Metacognição, Perfil Empreendedor e Percepção de Sucesso. Tese de doutorado, Universidade Federal da Bahia, Salvador, BA, Brasil.

Ferreira, M. P. V., Pinto, C. F., \& Miranda, R. M. (2015). Três décadas de pesquisa em empreendedorismo: uma revisão dos principais periódicos internacionais de empreendedorismo. READ. Rev. eletrôn. adm., 21(2), 406-436.

Ferreira, M. A., Colares, A. C. V, Rocha, P. M., \& Carvalho Junior, L. E. (2013). O Ensino de Empreendedorismo nos Cursos de Graduação em Ciências Contábeis. Revista Catarinense da Ciência Contábil, 12(35), 63-78.

Flavell, J. H. (1987). Speculations about the nature and development of metacognition. Hillside, NJ: Erlbaum.

Flavell, J. H. (1979). Metacognition and cognitive monitoring: A new area of cognitivedevelopmental inquiry. American Psychologist, 34(10), 906-911.

Gewehr, D., Strohschoen, A. A. G., \& Schuck, R. J. (2020). Projetos de pesquiisa e a relação com a metacognição: percepções de alunos pesquisadores sobre a própria aprendizagem. Revista Ensaio, 22. 
Hair, J. F., Hult G. T. M., Ringle, C. M., Sarstedt, M., \& Thiele, K. O. (2017). Mirror, mirror on the wall: a comparative evaluation of composite-based structural equation modeling methods, Journal of the Academy of Marketing Science, Springer, 45(5), 616-632.

Hair, J. F., GabrieL, M. L. D. S., \& Patel, V. K. (2014). Modelagem de equações estruturais baseado em covariância (CB-SEM) com o AMOS: orientações sobre a sua aplicação como uma ferramenta de pesquisa de marketing. REMark-Revista Brasileira de Marketing, edição especial, 13(2), 44-55.

Haynie, M., \& Shepherd, D. A. (2009). A Measure of Adaptive Cognition for Entrepreneurship Research. Entrepreneurship Theory and Practice, 33(3), 695-714.

Haynie, J. M., Shepherd, D., Mosakowski, E., \& Earley, P. C. (2010). A situated metacognitive model of the entrepreneurial mindset. Journal of Business Venturing, 25(2), 217-229.

Henseler, J., Ringle, C. M., \& Sarstedt, M. (2015). A new criterion for assessing discriminant validity in variance-based structural equation modeling. Journal of the academy of marketing science, 43(1), 115-135.

Hirst, G., Knippenberg, D. V., \& Zhou, J. (2009). A cross-level perspective on employee creativity: goal orientation, team learning behavior, and individual creativity. Academy of Management Journal, 52(2), 280-293.

Jones, J. L., Davis, W. D., \& Thomas, C. H. (2017). In competition engaging? Examining the interactive effects of goal orientation and competitive work environment on engangement. Human Resource Management, 56(3), 389-405, 2017.

Kock, N., \& Hadaya, P. (2016). Minimum sample size estimation in PLS-SEM: The inverse square root and gamma-exponential methods. Information Systems Journal, 28(1), 227-261.

Lima Filho, R. N. (2013). Empreendendo sobre o empreender e pensando sobre o pensar: um estudo sobre características empreendedoras e metacognição. (Tese de doutorado), Universidade Federal da Bahia, Salvador, BA, Brasil.

Lima Filho, R. N., \& Bruni, A. L. (2015). Metacognição estimula características empreendedoras? Uma análise em profissionais de administração. RACE, 14(2), 427-450.

Lima Filho, R. N., \& Nova, S. P. C. C. (2020). Diferenças de aprendizagem autorregulada em estudantes de pós-graduação: uma análise relacionando idade e gênero ao uso de estratégias. Revista Catarinense da Ciência Contábil, 19, 1-20.

Long, J. S. (1983). Confirmatory Factory Analysis: a prefacy to LISREL. Sage Publications, $7(33)$.

Moreira, M. A., Alves, N. J. F., Andreassi, T., \& Braga, J. G. R. (2020). Educação Empreendedora em Contabilidade: da Teoria à Aprendizagem Experiencial. Revista Catarinense da Ciência Contábil, 19(1). 
Oosterbeek, H., Praag, M. V., \& Ijsselstein, A. (2010). The impact of entrepreneurship education on entrepreneurship skills and motivation. European Economic Review, 54(1), 442-454.

Pajares, F., Britner, S., \& Valiante, G. (2000). Relation between achievement goals and selfbeliefs of middleschool students in writing and science. Contemporary Educational Psychology, 25, 406-422.

Pimentel, F. S. C., \& Sales Júnior, V. B. de (2021). Avaliação da consciência metacognitiva de usuários de jogos digitais. Aprendizagem baseada em jogos digitais: teoria e prática. Rio de Janeiro: BG Business Graphics Editora.

Reijonen, H., \& Komppula, R. (2007). Perception of success and its effect is small firm performance. Journal of Small Business and Enterprise Development, Finland, 14(4).

Ribeiro, C. (2003), Metacognição: um apoio ao processo de aprendizagem. Psicologia: Reflexão e Crítica, 16(1), 109-116.

Rocha, C. J. T., \& Malheiro, J. M. S. (2019). Metacognição e a experimentação investigativa: a construção de categorias interativa dialógicas. Revista Educação, 44.

Rosa, C. T. W., Corrêa, N. N. G., Passos, M. M., \& Arruda, S. de M. (2020). Metacognição e seus 50 anos: uma breve história da evolução do conceito. Revista Educar Mais, 4(3), 703721.

Sarstedt, M., \& Cheah, J. H. (2019). Partial least squares structural equation modeling using SmartPLS: a software review. Journal of Marketing Analytics, 196-202, 2019.

Schmidt, S., \& Bohnenberger, M. C. (2009). Perfil empreendedor e desempenho organizacional. Revista de Administração Contemporânea, 13(3) 450-467.

Staniewsky, M. W., \& Awruk, K. (2017). Questionnaire of entrepreneurial success: report on inicial stage of method construction. Journal of Business Research.

Urban, B. (2012). Applying a metacognitive perspective to entrepreneurship: empirical evidence on the influence of metacognitive dimensions on entrepreneurialintentions. Jornal of Enterprising Culture, 20(2), 203-225. 